\title{
Does Idiosyncratic Return Volatility Capture Information or Noise?
}

\author{
Claudia Pereira ${ }^{\mathrm{a}}$ and Antonio Cerqueira ${ }^{\mathrm{b}}$ \\ a Polytechnic of Porto, CEOS.PP - Center for Organisational and Social Studies of P. Porto, S. Mamede \\ de Infesta, Portugal, claudial@iscap.ipp.pt \\ ${ }^{\mathrm{b}}$ University of Porto, School of Economics and Management, Porto, Portugal, acerqueira.pt@gmail.com
}

\begin{abstract}
This paper examines the association between earnings management and firm-specific return volatility for a sample of firms listed on the London Stock Exchange. Identifying the determinants of idiosyncratic volatility has been a topical issue since the Campbell et al. (2001) study which documents a noticeable increase in average firm-level volatility across time. Using panel data, we find that poor information environments resulting from earnings management is associated with higher firm-specific return volatility. This finding is consistent with the noise-based approach of firm-specific return volatility. In addition we provide empirical evidence that such association gets stronger when combining accruals quality and the dispersion in analysts' forecast to describe a poor information environment. These findings are likely to contribute to the debate on whether firm-specific return volatility captures more firm-specific information being impounded in stock prices or essentially reflects noise.
\end{abstract}

JEL Classification: G12, G14, M40

Keywords: Idiosyncratic Volatility, Earnings Management, Accruals Quality. 